\title{
古代ローマの記念門のアーチ幅と軀体幅との関係について (共和政末期からユリウス・クラウディウス時代まで) \\ PROPORTIONAL ANALYSIS ON THE RELATIONSHIP BETWEEN WIDTH OF ARCH AND WIDTH OF PILLAR IN THE ROMAN COMMEMORATIVE ARCH UNTIL JULIO-CLAUDIAN PERIOD
}

渡辺道治*

Michiharu WATANABE

\begin{abstract}
The present papaer discusses proportional relationship between width of arch and that of pillar in the Roman commemorative arch until Julio-Claudian period. Between those width, having no relation with the difference of passages, we perceive simple ratios on intergral number. Among the various ratios, several of them are same in some commemorative arches. In the commemorative arch with three passages, especially, the ratio itself between each axial width of four pillars are common to that in the arch with single passage.
\end{abstract}

keyword : Ancient Roman Architecture, Roman Commemorative Arch, plan, proportional analysis, width of arch, ローマ建築, ローマの記念門, 平面, 比例分析, アーチ幅

\section{1 はじめに}

本稿は、古代ローマの記念門におけるアーチ幅とその 両脇の軀体幅（以下ここでは単に軀体幅と記す）との寸 法上の関係についての分析を行い、そこに共通する特性 ならびにその特性の年代的な変化を明らかにすることを 目的とする。まず、本稿では記念門が出現した共和政末 期からユリウス・クラウティウス時代頃までを対象とし ウェシパシアヌス時代以降は次稿で取り扱う。記念門の 建築形態はきわめて単純であり、そうであるからこそア 一千幅之銵体幅はこの建筑の形を决定的にする最も重要 な要素である。ここで行う分析はあくまでもア一チ幅と 軀体幅における寸法上の関係を導くことに限定され、必 ずしも設計の過程を想定し、その検証を行うものではな い。現在の研究状況では、設計過程全体を明らかにする に充分な考古学上もしくは文献上の資料が極度に欠けて いるからである。

記念門の平面は、建築としてはきわめて単純な形を示
している。しかし、その平面や立面の各部の寸法の間に いかなる関係があるのかについてほとんど解明されてい ない。わずかに若干の事例において分析が試みられてい るが、そこに見られる最大の問題点は分析方法ならびに 結果が個別的であり、いくつかの事例について共通する 特性を抽出するまでには至っていないことである。既往 研究における疑問点をあげれば、たとえば実測值と分析 のために設定された基準線との誤差がきわめて大きいこ と、また設定されたこの基準線が建築的に意味のある点 におかれていない場合がしばしば見受けられることであ る(1)。

\section{2 分析の前提条件}

記念門各部の寸法上の関係について、古代の建築家や 著述家はなにも我々に残してはいない。また、考古学上 の資料においてもそれを直接的に示してくれるようなも

\footnotetext{
*. 九州東海大学工学部建築学科 助教授·博士 (工学) Assoc. Prof., Dept. of Architecture, Faculty of Engineering, Kyushu Tokai Univ., Dr. Eng.
} 
のはまだ確認されていない。したがって記念門のアーチ 幅と軀体幅との寸法上の関係を明らかにするには、現存 する遗構を綿密に調べ、そこから推論する以外に方法は 残されていない。そこで、筆者はこの分析を行うに際し て論理的とみなせる以下の五つの前提条件が必要である と考える(2)。

（a）記念門という建築形態の各部の間には寸法上なんら かの関係が存在し、それは比例関係が最も可能性が高い であろう。古代エシプト、ギリシア、ローマ時代を通じ て建筑図面らしきものが断片的に発見されている(3)。 このことは、ローマ時代すでに充分な建築的計画をもっ て記念門が建設されていたことを窥わせるものである。 また、ローマ時代の建筑に関する唯一の文献資料である ウィトルウィウス建築書を見ると、エトルリアやローマ 神殿あるいは劇場の平面計画において、比例関係が全体 の主要な寸法を决定する主要因となっている(4)。した がって、記念門でも全体のおもだった部分の寸法の間に は比例関係が存在したと見てよいであろう。

（b）できるかぎり単純な比例関保ほど蓋然性が高い。同 じ比例関係といっても様々な比例関係が存在する。しか し実際に建設に移す場合を想定すれば、より単純な比例 值の方がより利便性が高いことは明らかである。

（c）分析を行う際に、その基準となる線は建築構成上意 味のある点でとる。換言すれば、外法、内法、あるいは 壁の中心線のどれかに統一する。

（d）事例数がある程度の数に達し、かつ時代的あるいは 地域的に極端な偏りがない。これは導かれた推論に普遍 性を与え、かつ地域や年代による特殊性を排するためで ある。

（e）より多くの事例数に共通する比例関係ほど普遍性が 高いとみなす。これは、個々の記念門がもつ特殊性を排 除するためである。

\section{1寸法のとり方について}

アーチ幅と軀体幅は、基壇あるいは柱台の下部荆形の 直上部分の高さにおいてとる。基壇や柱台がない場合は、 賉体の下部刮形の直上部分の高さにおいてとる。また図 1にみられるように、迫持ち柱や付け柱の突出部分を除 いた駱体本体の幅やアーチ幅を用いることを原則とした。 三連ア一チの記念門ではアーチを支持する四つの軀体の 中心線間の距離も別に考虑にいれた。アーチ幅と軀体幅 の略記号は図 1のとおりである。

\section{2 実測值と理論値との差について}

分析結果の妥当性を判断する有効な指標のひとつが、 実測値と比例関係から導かれた理論值との相違の小ささ
である。その相違の許容範囲は記念門の施工精度や、保 存状態、あるいは実測の精度によって異なってくる。そ こで筆者はその許容範囲をほぼ１\%ほどと規定した。な せなら、当然同じ寸法であるべきアーチ両脇の軀体の長 さを左右で筆者が実測し、その相違をその長さに対する 割合で比較してみると、その割合は 0.5〜 3\%ほどの間 におさまっており、1\%ほどが最も多いからである。

\section{3 資料について}

取り扱う事例総数は44例であり、本稿ではまず19例を 取り上げる。残りの25例は次稿で取り扱う。考古学上お よび文献上の資料から記念門と考えられる事例数は約 3 80ほどあるのに比較すると、その数は全体のほぼ一割に すぎないことになる。しかし、現存する遗椣として確認 できる事例数は 380例のうちの三分の一ほどであり、こ の40例ほどの事例数の分析でおよその傾向は把握できよ う。次にその建設年代と地域の偏り具合を検討してみる。 建設年代をみると、前一世紀に 3例、一世紀に16例、二 世紀に11例、三世紀に10例、四世紀に 2例、建設年代不 明が 2例である。地域的にみると、西地中海都市に37例 で、このうちヨーロッパに22例、北アフリカに15例と分 かれ、東地中海都市に7例である。つまり、取り扱う資 料の建設年代や地域上の特別な偏りはみられなく、ロー マ時代全体にわたって、かつその帝国全土の傾向として の分析結果と捉えてもさしつかえないであろう。

最後に資料の出典について述べたい。をれぞれの記念 門各部の寸法はできるかぎり筆者の㬰測調查をもとにし た。調査はイタリアとアルシェリアではスチール製の 5 $\mathrm{m}$ と $30 \mathrm{~m}$ のメジャーで、フランスとチュニジアでは上記 二つのメジャ一およひ簡易超音波測距離計で実測した。
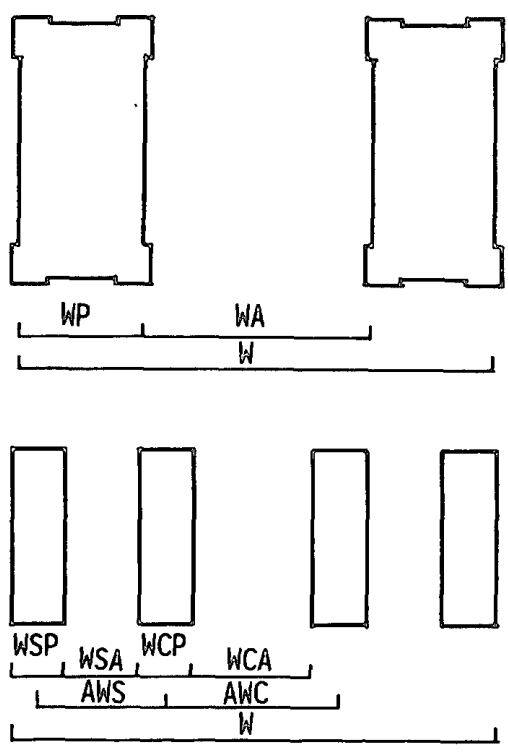

図 1 各部の寸法の取り方 
実測の単位はmmまでとした（ただし超音波測距離計はcm まで）。また、維密な実測調査の報告書が刊行されてい る場合には、そこに記載された寸法を採用した。

\section{1 アーチ幅と甥体幅との比例関係}

表 1に、記念門のアーチ幅と軀体幅の比例関係につい てまとめた。表の左欄より右に都市名、現在の国名、記 念門の名称、通路数、建設年代、全体の幅（表 1 (1) の項）、稫体幅（表 1の（2）の項）、ア一千幅（表 1 の (3)の項）、アーチ幅に対する監体幅の比、その近似の 整数比（表 1 の（4)の項）、整数比から導いた軀体幅と その実測值との差、寸法の出典を示している。

ただしウェローナのガウィウス家の記念門は正面と側 面の寸法の異なる四面門であるので、上段に正面の、下 段に側面の実測值とその分析結果を示した。また二連や 三連アーチの記念門の場合では左闌から右欄に並ぶ項目 は同じであるが、実測場所による寸法や分析の結果の相 違を示すために数段にわけて表示した。まず二連アーチ の記念門であるサントの場合は、上段に中央の軀体幅と それに対応した比例関倸を、下段に両端の軀体幅とそれ に対応した比例関倸を示した。三連アーチの記念門の場 合には上段に両脇二つの軀体の中心線間距離を(2) の欄 に、中央二つの軀体の中心線間距離を(3) の欄に示し、 それらの比例関係を（4)欄以降に記した。中段には中央 二つの稫体幅と中央のア一千幅、それに関連する比例関 係を、下段には両端の軀体幅と両端のア一チ幅、そして それに関連する比例関係を表示した（図1参照）。

まず、単一アーチの記念門のアーチ幅と軀体幅との比 例関倸から見ていくことにしょう。

イタリアのアウグストゥス時代からクラウティウス時 代までの記念門では、ア一千幅と軀体幅との間には単純 な比例関係が見いだせる。建設年代の判明する最古の現 存遺構であるリミニのアウグストゥス記念門（紀元前 27

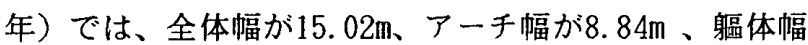
が3.09m である。これを当時のローマ尺に換算するとそ れぞれ503/4尺、30尺、10 1/2尺となり、驅体幅とア一 チ幅はほぼ 1:3の比をなす。ほぼ同じ時期に建設された アオスタの記念門（紀元前25年）では、軀体幅が5. $312 \mathrm{~m}$ 、

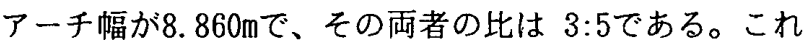
より約 20 年後に建設されたスーサの記念門でも驅体幅は

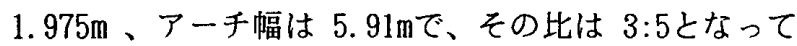
いる。稫体幅とアーチ幅が同じ 3:5の比をなす例として、 同じアウグストゥス時代に建設されたプーラのセルギウ ス家の記念門があげられる。

次に四面門の形をとるヴェローナのガウィウス家の記 念門では、正面と側面それぞれにおいて軀体幅とアーチ 幅との間に単純な比例関係が成立している。正面では軀
体幅とアーチ幅は等しく、その比は $1: 1$ となる。側面で は両者の間に $2: 3 の$ 比がみいだせる。またスポーレトの

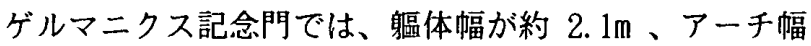
が4.2mで、その両者の比は 1:2である。64年のヴェスヴ ィウス炎山の噴火後に修復もしくは再建されたと考えら れるポンペイのフォルムのジュピター神殿の西側の記念 門では、その軀体幅とアーチ幅の比は 4:7である。

アーチ幅と軀体幅が単純な整数比をなすのは、ローマ 帝政初期の南フランスの記念門にも共通することである まずカルパントラとカヴァイヨンの記念門では、軀体幅 とアーチ幅は $1: 3 の$ 比をなし、リミニやスーサの記念門 の場合と等しい。またサン・シャマの記念門では躬偪体幅 とアーチ幅との間に 3:5の比を示し、アオスタの記念門 之共通する比を持っている。またグラヌムの記念門では 軀体幅3.530m、アーチ幅が5.355mで、その両者の比は 2 :3となり、やはり単純な整数比をなしている。同じ南フ ランスのエクス・レ・バンの記念門でも、軀体幅とアー チ幅との間には $2: 3 の$ 比が成立している。

単ーアーチの記念門の軀体幅とアーチ幅との間にみら れる単純な整数比は、二連や三連アー千の記念門におい てもみいだせる。二連ア一チを持つサントのティベリウ 又記念門では、両端の軀体の幅が $2.570 \mathrm{~m}$ 、中央の軀体 幅が2.234m、アーチ幅が $3.910 \mathrm{~m}$ である。したがって、 両端の軀体幅とアーチ幅の比は $2: 3 の$ 比をなし、グラヌ 么の記念門と同じ比である。中央の軀体幅が両端の軀体 幅に比較して $0.336 \mathrm{~m}$ 、すなわち約 1ローマ尺狭くなっ ている。この軀体幅の微妙な相違は、二連アーチの記念 門という特異な平面形式に起因するものと考えられる。 つまり、二連アーチの記念門では単一ア一チや三連アー 千の記念門に比較して平面や立面における中心性がきわ めて弱い。そこで二連アーチであるサントの記念門では この欠点を補うために、中央の軀体幅を両端の軀体幅よ りも1ローマ尺だけ狭くするという手法が取り入れられ たと解釈できる。

三連アーチを持つオランジュの記念門ではきわめて興 味深い比例関係がみいだせる。まず中央ア一チ部分で、 両脇の軀体幅とアーチ幅は $1: 3 の$ 比をなしている。これ はリミニの記念門と同一である。次に両端のアーチ部分 については、軀体幅とアーチ幅の比は $2: 5$ である。さら に四つの軀体の中心線間の距離についてみると、両側の 中心線間距離と中央の中心線間の距離の比は $2: 3$ となる。 この比はグラヌムやサン・シャマの記念門の場合と共通 する値である。つまり、三連アーチの記念門においても ア一チ幅と軀体幅との間に単純な比例関保が成立し、し かも四つの軀体の中心線間距離においても同じょうに単 純な比例関係が成り立っているのである。その上、その 比例值そのものも、単一ア一チの記念門にみいだされた 值と共通しているのである。 
褧 1 記念門のアーチ幅とその両脇の膒体幅との関係

\begin{tabular}{|c|c|c|c|c|c|c|c|c|c|c|c|}
\hline 都市名 & 名 & 記念門の名称 & $\mathrm{P}$ & 建設年代 & $\begin{array}{l}\text { (1) } \\
W\end{array}$ & $\begin{array}{l}\text { (2) } \\
\text { WP, AWS } \\
\text { WCP } \\
\text { WSP }\end{array}$ & $\begin{array}{c}\text { (3) } \\
\text { WA, AWC } \\
\text { WCA } \\
\text { WSA }\end{array}$ & $(2) /(3)$ & (4) & $\begin{array}{l}\text { (4) } \times(3) \\
-(2)\end{array}$ & 出 \\
\hline Rimini & IT & Arch of Augustus & 1 & 27 B.C. & 15.020 & 3.09 & 8.84 & 0.349548 & $1: 3$ & -0.413 & $\mathrm{R}$ \\
\hline Aosta & IT & Arch & 1 & c. 25 B.C. & 19. 484 & 5. 312 & 8.860 & 0.599549 & $3: 5$ & 0.004 & $R$ \\
\hline Aquino & IT & so called Arco di Antonino & 1 & $\begin{array}{l}\text { end I C. B. C. } \\
\text { beg. A. D. } 1 \text { C }\end{array}$ & 6.10 & 1.20 & 3.70 & 0.324324 & $1: 3$ & 0.033 & $\mathrm{R}$ \\
\hline Susa & IT & Arch of Augustus & 1 & $9 \sim 8$ B.C. & 9.85 & 1.925 & 6.00 & 0.320833 & $1: 3$ & 0.075 & $\mathrm{R}$ \\
\hline Cavaillon & FR & Arch & 1 & $1 \sim 10$ & 5.496 & 1.104 & 3.300 & 0.334545 & $1: 3$ & -0.004 & W \\
\hline Pula & YU & Arch of Sergius & 1 & 2 B. C. A. D. 14 & 8.57 & 2.32 & 3.93 & 0.590331 & $3: 5$ & 0.038 & $\mathrm{R}$ \\
\hline Glanum & FR & Arch & 1 & $10 \sim 20$ & 12.440 & 3.530 & 5.355 & 0.659197 & $2: 3$ & 0.040 & $\mathrm{R}$ \\
\hline Arles & FR & Arch & 1 & Augustan & 10.140 & 2. 970 & 4.200 & 0.707143 & $7: 10$ & -0.030 & $\mathrm{R}$ \\
\hline Aix-les-Bains & FR & Arch & 1 & Augustan & 7.162 & 1.640 & 3.898 & 0.420729 & $2: 5$ & -0.081 & W \\
\hline Philippi & GR & Arch of Augustus & 1 & Augustan & 10.74 & 2.88 & 4.98 & 0.578313 & $4: 7$ & -0.034 & $\mathrm{R}$ \\
\hline St-Chamas & FR & Arch & 1 & beg. A. D. 1 C. & 7.777 & 2. 092 & 3.547 & 0.589794 & $3: 5$ & 0.236 & W \\
\hline Spoleto & IT & Arch of Germanicus & 1 & 23 & 8.380 & 2.110 & 4. 160 & 0.507212 & $1: 2$ & 0.060 & W \\
\hline Carpentras & FR & Arch & 1 & A. D. $1 \sim 37$ & 7.607 & 1.512 & 4. 414 & 0.342546 & $1: 3$ & -0.041 & W \\
\hline Leptis Magna & $L Y$ & Arch of Tiberius & 1 & $35 \sim 36$ & 4. 72 & 0.50 & 3.72 & 0.134409 & $1: 8$ & -0.035 & $\mathrm{R}$ \\
\hline Verona & IT & Arch of Gavius & 4 & Tiberian & $\begin{array}{r}10.67 \\
6.11\end{array}$ & $\begin{array}{l}3.57 \\
1.74\end{array}$ & $\begin{array}{l}3.51 \\
2.65\end{array}$ & $\begin{array}{l}1.017094 \\
0.656604\end{array}$ & $\begin{array}{l}1: 1 \\
2: 3\end{array}$ & $\begin{array}{l}0.060 \\
0\end{array}$ & $\mathrm{R}$ \\
\hline Pompei i & IT & West Arch in Forum & 1 & A. D. $1 \sim 69$ & 6.191 & 1.644 & 2.903 & 0.566311 & $4: 7$ & 0.015 & W \\
\hline Saintes & IT & Arch of Tiberius & 2 & 19 & 15.204 & $\begin{array}{l}2.234 \\
2.570\end{array}$ & $\begin{array}{l}3.910 \\
3.910\end{array}$ & $\begin{array}{l}0.571356 \\
0.657289\end{array}$ & $\begin{array}{l}4: 7 \\
2: 3\end{array}$ & $\begin{array}{l}0 \\
0.023\end{array}$ & W \\
\hline Ephesus & IT & Arch of Mazaeus \& Mitridates & 3 & $4 \sim 3$ B.C. & 16. 93 & $\begin{array}{l}5.61 \\
1.28 \\
1.28\end{array}$ & $\begin{array}{l}4.985 \\
4.23 \\
4.87\end{array}$ & $\begin{array}{l}1.125376 \\
0.302600 \\
0.262834\end{array}$ & $\begin{array}{l}9: 8 \\
3: 10 \\
3: 11\end{array}$ & $\begin{array}{c}-0.002 \\
-0.011 \\
0.048\end{array}$ & $\mathrm{R}$ \\
\hline Orange & IT & Arch & 3 & $20 \sim 26$ & 15.310 & $\begin{array}{l}5.155 \\
1.915 \\
1.43\end{array}$ & $\begin{array}{l}7.68 \\
5.80 \\
3.53\end{array}$ & $\begin{array}{l}0.671224 \\
0.330172 \\
0.405099\end{array}$ & $\begin{array}{l}2: 3 \\
1: 3 \\
2: 5\end{array}$ & $\begin{array}{r}-0.035 \\
0.018 \\
-0.018\end{array}$ & $\mathrm{R}$ \\
\hline
\end{tabular}

単位はすべて m。

(1)：記念門の全体幅

(2) : アーチ両脇の毁体幅
$P:$ 通路敨 end:後期 beg:初期

(3): アアーチ幅

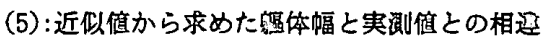

ただしSaintes の堨合は上段は中央の睗体幅、下段は両脇の艋体幅。Veronaは四面門であるから上段に正面側、下段に側面側の寸法と分析

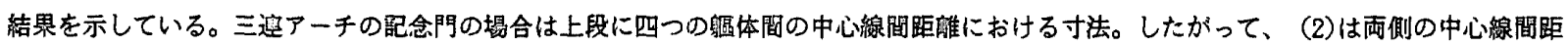

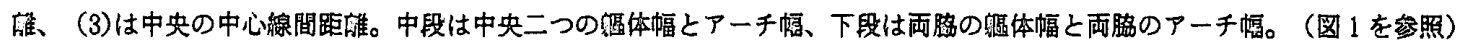
出典について $\mathrm{W}$ : 管者の実測 $\mathrm{R}$ : 発掘報告㣙らび研究仙による。それぞれの出典は以下の通りである。

Rimini:G.A.Mansuelli, L'Arco di Augusto inRimini, in Emilia romana, vol.12,1944, fig. 1, pp. 140-157. /Aosta: C.Promis, Antichitá di Aosta, Torino, 1862, tav. 12, 13. / Aquino: M. Cagiano de Azevedo, L'Arco di Aquino e un disegno di Giuliano da Sngallo, in Palladio, vol.16, 1938, fig. 6. Susa: E. Ferrero, L'Arc d'Auguste à Suse, Mllano, 1901, pp.1-5. /Pula: G. Traversari, L'Arco dei Sergi, Padova, 1971, tav. 1. /Glanum:L'Arc de Glanum, Paris, 1977, pl.3. / Arles: A. von Gradiss, Der 'Arc du Rhone', in R.M., vol. 79, 1972, pp. 22-87. /Philippi: P. Collart. Philippes ville de Macedone depuis ses origines jusq' à la fine dell' epoque romaine,

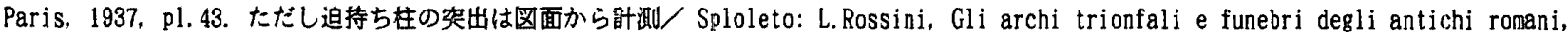
Roma, 1836, tav. 33-34. 迫持ち柱の实出は篮者の実測/ Leptis Magna: P. Romanelli, Gli archi di Tiberio e di Traiano in Lep:"is Magna, in Africa italiana, vol.18, 1840, pp. 87-96. / Verona: G. Tosi, L'Arco dei Gavi, Roma, 1983, tav.1-2./ Ephesus: W. Wilberg, Forshungen in Ephesus, vol.3, Wien, 1923, fig. 64. / Orange: R. Army et al.. L'Arc d'Orange, Paris, 1983, pl.1. 
次に、東地中海都市のフィリッピとエフェソスの記念 門についてみてみよう。フィリッピの記念門では躬体幅 が 2.880m、ア一千幅が $4.980 \mathrm{~m}$ である。したがって、

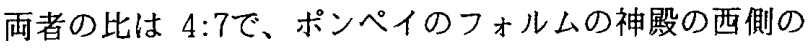
記念門と同一である。

エフェソスのマツァエウスとミトリダテスの記念門は 三連ア一チである。ここではオランシュの記念門でみた ような中央ア一チ幅とその両脇の軀体幅の比、あるいは 両脇のアーチ幅と端部の聐体幅との間に単純な整数比は 見いだせない。また、その中央二つの軀体の中心間距離 は $5.605 \mathrm{~m}$ 、その両脇の中心線間距離は $4.985 \mathrm{~m}$ で、そ こにも整数比は見いだし難い。しかし、この二つの中心 線間距離の相違は正面のア一チを支持する軀体の処理法

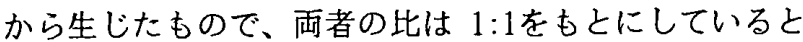
考えられる。この記念門はアゴラの柱廊と構造的に一体 化させるという要求から、両端の軀体の中心線間の距離 $16.20 \mathrm{~m}$ はアゴラの柱廊の内側柱列の三スパン分に対応 している。そのため記念門の内側の躳体は、あくまでも アゴラの柱廊内側の柱列の真々間距離に対応して配され ている。ただし正面中央の二つの䮠体は、中央アーチを 支持する軀体の内側で戸口の方立てを省略し、かつ片蓋 柱を中央側に寄せたために四つの軀体の中心線間距離が 等しくならなかったのである。このようにやや特殊では あるものの、エフェソスの記念門でもオランジュの場合 と同様に三つの中心線間距離の間に単純な比例関係が成 立している。

最後に、アーチ幅と軀体幅の比について若干特異な記 念門であるアルルとレプティス・マグナの場合について 記しておきたい。これまで述べてきた記念門では、軀体 幅とアーチ幅の間にしばしば 1:3、2:3、3:5などの比 例が認められた。しかしアルルでは7:10、レプティス・ マグナでは 1:8の比をなし、やや特殊である。アルルの

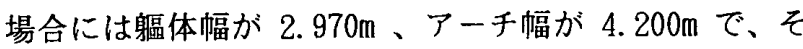
れぞれ10ローマ尺と14ローマ尺ほどにあたり、むしろ区 切りの良い絶対的な長さから決められた可能性がある。 レプティス・マグナでは躬体幅が $0.50 \mathrm{~m}$ (1 2/3 ローマ 尺）、アーチ幅が $3.72 \mathrm{~m}(121 / 2$ ローマ尺) である。こ こでは 1:8の比を持つともいえるが、街路に跨がって衝 立のように立つ小規模な記念門であるから、構造的にも つ最小の壁の幅と道路の幅員という実際的な要求からそ の大きさが定まったともいえよう。

\section{4.まとめ}

現存遺構の実測から、一世紀後期頃までの古代ローマ の記念門のア一千幅とその両脇の軀体幅との間の比例関 係の分析から以下の点が明らかになった。

第一に、両者の間に $1: 3 、 2: 3 、 2: 5 、 3: 5$ などきわ
めて単純な整数比が成り立っている。

第二に様々の比例値が見いだせるが、共通した比例值 がしばしば綝り返し現れている。とりわけよく現れる比

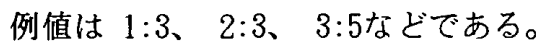

第三に、記念門の通路の数に無関係にこうした単純な 整数比がみいだせる。ただし三連アーチの記念門の場合 には、特にアーチを支持する四つの軀体の中心線間の距 離の間にこうした関係をみいだせる。たとえば二連アー チのサントのティベリウス記念門では、両脇の驅体幅と

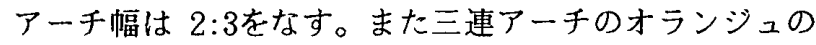
ティベリウス記念門では、雨脇の二つの軀体の中心線間 の距離と中央二つの軀体の中心線間の距離との間に $2: 3$ の比が成立している。

(注)

(1) 平面や立面における建築形態の幾何学的な既往研究は、おおまかに以下 の四つにわけられる。（a）アーチ幅を基準として全体の幅や高さをその倍数 で表す。たとえばつェレロ (E. Ferrero, L'Arc d'Auguste à Suse, Milano. 1901, p. 3, pl.1.) やストゥキの分析(S. Stucchi, Divagazioni archeologiche, vol.2. Roma，1981の中に見られる数例の記念門の立面の分析図）。しかし その分析では立面图に円が重ねて描かれているため、アーチ幅として迫持ち 柱の突出をいれるのかいれないのか、あるいは䪵体幅として付け柱の突出を 考虑するのかどうかなど不明な点が多い。（b）ルート2を基华とした分析。 代表例としてプリリアントによるローマのセプティミウス・セウェールス記 念門の立面分析 ( R. Brilliant. The Arch of Septimius Severus in the Roman Forum, in M. A. A. R. . vol. 29. 1967, pp. 41-44, pl.2.)。その分析は ひとことで言えは䙓雑侱奇といかさるを得ない。数多くの基染線が立面に引 かれ、それらが実際の立面においてどのような意味を持つのか不明確な上、 ルート2 の比で相互に結び付けられている部分同士が建築上意味を持つとは 思えない。(c) 三角形を活用する。立面の中心上に常に三角形の頂点を固い て相似の三角形をいくつか描き、それらの三角形の三つの頂点上に立面の主 要な点にのるという分析方法。例として G. Traversari, L'Arco dei Sergi, Padova, 1971, pp. 89-90, pl.5., N. Ferchiou, L'Arc de Gordien III à Mustis, in Africa, vol.9. 1985, pp. 102-103. fig. 5.。類似した方法を平 面に適用した例もみられる (J.Bruchet, L'Arc de Glanum(ed. H. Holland), in XXXI Supplement a (allia, vol.37, 1977, p. 47, pl.28)。この分析法 では、図形上得られる点と実際の点との相連か大きすぎかつ図形上得られ た点が必ずしも建勧上重要とは思えない点も多い。（d）モテュールを用いる。 すなわち格子を立面に重ね、この格子の線上に立面各部の主要な点がのると いう分析方法（たとえば G. Tosi， L'Arco dei Gavi， Roma. 1983. pp. 62-67. tav.5.)。このウェロローナの分析では格子上にのる場合もあればのらない場 合もあり、説得力に欠ける。

これら既往の分析では、個々の記念門研究の一項目として平面と立面（特 に立面)の幾何学的な分析が行われている。したがって、ほかの記念門の婸 合も考虑に入れて分析が行われているかけではなく、対象となった記念門に 最も適合しそうな方法が取られている。その結果、分析方法になんらの一貫 性もなく、分析方法そのものも礁立されてはいない。

（2）キリシア神殿のスタイロベートと柱間寸法の間の比例関係の分析を行っ たカルトンは分析にあたりその前提条件として以下の三点をあげている。理 詥上の比例值と実测值の相连が小さいこと、比例值が単純であること、比例 值が数多くの逐構に当てはまること、である (J.J.Coul ton. Towards Under standing Greek Temple Design:General Consideration, in B.S.A., vol.7 0.1975, p. 62.) 。

（3）エシプトの゚ピルスに描かれた図、石版に刻まれたギリシア時代の神殿 の整盤の図、ローマ時代のクラウティウス期のクラウディア・ペロリスの墓 㡿の平面図など。

(4) Vitruvius. De Architectura, IV, VII など。

（1994 年 5 月 10 日原稿受理，1994 年 9 月 19 日採用決定） 